\title{
Occupational Health and Safety among Street Traders in Nigeria
}

\author{
Isaiah Oluranti Olurinola ${ }^{1}$, Theophilus Fadayomi ${ }^{2}$, Emmanuel O. Amoo ${ }^{1} \&$ Oluyomi Ola-David ${ }^{1}$ \\ ${ }^{1}$ Department of Economics and Development Studies, School of Social Sciences, Covenant University, Nigeria \\ ${ }^{2}$ Department of Economics, Elizade University, Ondo State, Nigeria \\ Correspondence: I. Oluranti Olurinola, Department of Economics and Development Studies, Covenant \\ University, Nigeria. Tel: 234-80-3332-2048. E-mail: olu.ogunrinola@covenantuniversity.edu.ng
}

Received: December 23, 2013

Accepted: January 22, 2014

Online Published: March 25, 2014

doi:10.5539/ijef.v6n4p59

URL: http://dx.doi.org/10.5539/ijef.v6n4p59

\begin{abstract}
This study examined two important types of occupational hazards in the street trading activities in Nigeria which are (i) injuries sustained from road traffic accident and (ii) harassment of traders through indiscriminate arrest, seizure and confiscation of merchandise and occasional incarceration of sellers in police cells. The data for the study was generated from a 2011 national survey of 3,873 street traders in Nigeria which was made possible through a research grant provided by the Covenant University's Centre for Research and Development. In addition to the descriptive statistics used in profiling the street traders, the binary logistic regression approach was also used to estimate the log of odds of experiencing occupational hazards in street trading activities. The study found out that 25 percent of the traders have suffered injury, while 49.1 percent have experienced harassment from public authority officials. Given these findings, policy measures that would focus on integrated national development, provide alternative selling points off the main streets for traders who cannot hire a shop, create more decent jobs for educated youths who are forced to take up street trading due to long spell of unemployment, among others, were proposed.
\end{abstract}

Keywords: street traders, occupational hazards, informal sector, employment, logistic regression, migrants

\section{Introduction}

This study is concerned with the occupational safety and health of workers. The provision of safe working environment in the formal sector of the economy is the normal role of a firm looking for ways to maximize its returns. By investing in the safety and health of workers, a profit maximizing firm minimizes its internal production costs as the provision of safe gadgets and decent working environment enhances safety of workers and improve productivity. The equilibrium level of safety is the point where the rising marginal cost of job safety intersects the downward sloping marginal benefit from job safety (McConnell, Brue, \& Macpherson, 2010). However, evidences in most countries have shown that the level of safety attained is affected by a low level of investment in safe working environment by private firms and this has motivated public intervention to reverse the trend. One important way of such public intervention into the labour market is through governments' enactment and enforcement of the laws required for safety in the work place. Such laws provide among other issues, safety regulations and minimum wage levels. With particular reference to occupational health and safety, governments do intervene by promulgating laws to regulate minimum health and safety conditions for work in factories, mines and workshops; and laws relating to compensations for temporary and permanent disabilities and death (Roever, 2006; Tsitsi, 2003).

However, the situation in the informal sector of the economy is different. The enterprises in this sector operate without binding official regulations (NBS, 2010; Ogunrinola, 1991; Ogunrinola, 2011). There are evidences of inadequate safety and environmental hazards in the informal sector generally and in street trading in particular. For instance, hawkers on the street carry out their occupation among slow moving vehicles with their wares balanced on their heads, and this exposes them to all kinds of dangers. Most of these workers do not have the necessary awareness and/or resources to implement health and safety measures. The public officials that work with these classes of workers are not there to help or protect but to collect levies or arrest them for constituting a nuisance in cities. In terms of research attention, the focus is more on formal sector compared to the informal. Thus, not much is known with respect to the level and extent of occupational safety and health in street trading which is, arguably, the largest and most visible part of the informal sector activities in most developing 
economies of the world (Dorman, 2000). The main objective of this study therefore is to examine the nature of occupational hazards in informal sector trading with a view to determining the factors responsible for them. The remaining sections of this paper are organized as follows: section two gives a brief survey of literature; section three highlights the research method; section four gives the analyses of data and discusses the results, while section five concludes the paper.

\section{Brief Review of Literature}

In the organised private sector, trade unions as well as relevant government agencies monitor firms' compliance to employee compensation laws and standards regarding health and safety of the employee in the work environment. The informal sector however lacks such degree of formal worker organization, thus making it a difficult case. In the developing countries where the informal economy represents a significant portion of the overall employment, it is expected that the informal sector would be given greater considerations with regards to occupational health and safety (WHO-ILO, 2000). Due to the nature and frequency of occupational injuries and diseases prevalent among workers in the informal sector and among small and medium enterprises, Rafei (2004) advocates increasing governmental attention to the matters of occupational health and safety. He noted that the absence of legislative, administrative and technological provisions for the sector account for the volume of casualties recorded from year to year. In addition, the ILO sponsored study conducted and reported by Comaru and Werna (2013) examined the health and safety related issues in informal sector enterprises and concludes by recommending safe practices that can enhance the health status of urban workers in the informal sector as this forms an important part of human capital formation and development.

The systematic analysis of the concept of human capital formation and its link with wages was popularized by the works of economists like Schultz (1961), Mincer (1974) and Becker (1975). The human capital theory, evident in the writings of Adam Smith (1776) reveals that it is not only the investment in physical capital that stimulates and propels economic growth, but also investment in the development of human capital. In his Wealth of Nations, Adam Smith maintained that 'a man educated at the expense of much labour and time may be compared to one of those expensive machines' (Smith, 1776). Thus, the theory of human capital emphasized the relationship between the level of an individual's earnings and her/his level of human capital accumulation over time. Therefore, any activity undertaken by labour (either solely or in conjunction with his employer) towards enhancing the quality or productivity of labour services supplied can be classified as human capital formation. One major item that qualifies as human capital is expenditure on education and training. In addition, expenditures on health care, migration, job search, and safe working environment among others, qualify as human capital formation (McConnell et al., 2010). This study is concerned with the occupational safety and health of workers.

To the individual, an addition to the present level of human capital stock involves both direct and indirect costs while the individual enjoys additional benefits in the form of increased earnings as a result of additional skills leading to enhanced productivity. The decision to invest or not to invest in additional human capital formation depends on whether the individual is fully informed of the relevant costs and benefits of the additional human capital to be attained. Hence the same investment appraisal method for physical capital is applicable to that of human capital where the net present value or the internal rate of return can be used. On the side of the firm, it makes an economic sense to invest in the human capital of employees if the expected discounted benefit is greater than the cost. Provision of safe working environment by a profit maximizing firm is one of the ways to increase the level of human capital. On the specific case of investment in the safety and health of workers (which is an aspect of human capital formation), a profit maximizing firm is expected to minimize its internal production cost through the provision of safe working environment among other ways. Thus, the provision of safety gadgets and decent working environment involves cost that must be paid by the firm with the expectation of receiving benefits of such investment. The equilibrium level of safety is the point where the rising marginal cost of job safety intersects the downward sloping marginal benefit from job safety (McConnell et al., 2010). However, evidences in most countries have shown a wide level of underinvestment in safe working environment by employers and this has motivated government intervention to reverse this trend.

One important way by which the government intervenes in the labour market is through the provision of a conducive environment for effective labour market transaction. Some of the ways by which this is carried out is through the enactment of laws to guide the actions of the labour market actors - the individual labour suppliers and their unions as well as the employees'/employers' associations. These laws have ways of enforcing safety laws and influencing the level of earnings and employment in the labour market, among others. However, for the informal sector in general and street trading in particular, the economic activities of participants involve high level of risks that often lead to several forms of occupational injury (and sometimes, death) for both peddling and 
sedentary sellers. It has even been argued in the literature that informal employment, in general, involves a higher risk relative to the formal sector workers in the same industry and occupation (Dorman, 2000). Since majority of the workers are self-employed with or without employees, the dearth of the required capital level makes the provision of Occupational Safety and Health (OSH) gadgets to be unaffordable for such entrepreneurs and therefore, majority of the workers do discharge their duties under unsafe and highly unhygienic conditions. For street traders, the conditions of work is even riskier as the peddlers sell within slow-moving traffic making them prone to risks of motor traffic accidents. Furthermore, the condition of work for street traders is worsened by the parading public authority officials (popularly known among street traders as 'Task Force') on Environmental Sanitation and Traffic Control who regularly engage in chasing away street traders from the highways within cities of Nigeria.

While research efforts are concentrated on the occupational health and safety in formal organisations in Nigeria and elsewhere, not much is known with respect to the level and pattern of occupational safety and health in the largest and most visible part of the informal sector activities which is street trading. For instance, Branigin (1997) observed that poor information is one major characteristic of the informal sector enterprises, and that workers in the informal sector are at high risk relative to their industry and occupation. This study intends to contribute to the scanty literature in this respect.

\section{Research Method}

The data for the study, which are from the primary source, were obtained by the authors in 2011 in a national survey of street traders. The survey was financed by the Covenant University Centre for Research and Development (CUCERD), Nigeria. The study, which is national in scope, interviewed 3,873 street traders in the Northern, Eastern and Western parts of Nigeria. Four major cities representing the former regional divisions of Nigeria were purposively selected for the study. The cities are Lagos, representing the West, Aba and Port-Harcourt for the East and Kano to represent the North. The direct interview approach was used as the principal method of data collection using two instruments: the questionnaire and the focus group discussions.

The random sampling approach was used in the selection of the sedentary sellers after having constructed an on-the-spot sampling frame. This was possible because they were settled and were always around their stalls (whether make-shift or semi-permanent). For the roving traders, sampling was a little difficult. A combination of direct observation method combined with random sampling techniques was used. This was done in stages. In the first place, enumerators arrived at their respective enumeration areas early to observe the traders selling in the early-hour peak period traffic of the day. While actively selling in busy traffic, they would not respond to interviews until the traffic situation eased and they find places to rest and wait for the next traffic build up. At the settling down spots, the enumerators treating each group as a stratum draw sample units from it, and where this did not succeed, a snowballing approach was adopted as a supplement. At the end of the survey exercise, three thousand eight hundred and seventy-three street traders were properly interviewed which resulted in an achievement rate of 86 percent out of the 4,500 planned respondents. In addition to this, focus group discussions were held for female street traders, male street traders and a mixed group of community members living in close proximity to the streets where many traders carry out their activities.

This study identified two types of occupational hazards faced by the street traders. The first is the one inherent in the type and nature of the job being done and this exposes the worker to occupational hazards. For street traders, the most pertinent form of hazard is the exposure to road traffic accidents which may range from being mild to being fatal. Other hazards latent in the job include inhalation of dust and fumes from badly maintained vehicles as well as obnoxious odour from blocked sewage system which are common sights in developing nations. The second form of occupational hazard relates to the harassment from the authorities who chase them from the street. Though such type of harassment to traders is non-selective, however not all of those interviewed had experienced confiscation of wares or an arrest leading to being locked up in police cells at any particular point in time. The respondents who are considered harassed are those whose goods have at one time or the other, been confiscated/destroyed, arrested and/or detained in police custody within the previous year period prior to the time of the interview.

To appraise the statistical significance of the results reported above, a binary logit model was formulated to identify those characteristics that explain occupational hazards among street traders in Nigeria. The dependent variable is the vulnerability of respondents to occupational hazards (whether injury or harassment) which is captured in binary form $(0,1)$ where 1 represents having had an injury from road traffic accident or harassment from public officials in the last one year while selling; and zero otherwise. A logistic regression analysis was therefore expressed as: 


$$
\mathrm{OSH}_{i}=L N \frac{P_{j}}{1-P_{j}}=\delta_{0}+\delta_{1} X_{1 j}+\delta_{2} X_{2 j}+\ldots+\delta_{n} X_{n j}+\epsilon_{j}
$$

$\mathrm{OSH}_{i}$ is the log of odds ratio of either being injured or being harassed in street trading activities; while the X's are the explanatory variables. The analysis of data was carried out with the Statistical Package for Social Sciences (SPSS) software.

\section{Results and Discussion}

\subsection{Socio-Demographic Profile of the Respondents}

Table 1. Selected socio-economic characteristics of respondents

\begin{tabular}{|c|c|c|c|c|c|}
\hline Gender & No & $\%$ & Region of Origin & No & $\%$ \\
\hline Male & 2260 & 58.4 & North central & 153 & 6.6 \\
\hline Female & 1613 & 41.6 & North east & 41 & 1.8 \\
\hline Total & 3873 & 100 & North west & 281 & 12.2 \\
\hline Age Group & & & South East & 667 & 28.9 \\
\hline Up to 14 years & 52 & 1.5 & South-South & 469 & 20.3 \\
\hline $15-24$ years & 1343 & 37.7 & South West & 653 & 28.3 \\
\hline $25-34$ years & 1466 & 41.1 & Non-Nigerians & 43 & 1.9 \\
\hline $35-44$ years & 496 & 13.9 & Total & 2307 & 100.0 \\
\hline 45 years above & 209 & 5.9 & Employment Status & & \\
\hline Total & 3566 & 100.0 & Self-employed & 3283 & 84.8 \\
\hline Nature of Trading & & & Employees & 293 & 7.6 \\
\hline Sedentary Traders & 1578 & 40.7 & Others & 297 & 7.7 \\
\hline Peddlers & 2295 & 59.3 & Total & 3873 & 100 \\
\hline Total & 3873 & 100 & & & \\
\hline Educational Attainment & & & Initial Capital & & \\
\hline No Schooling & 538 & 13.9 & Less than N20,000 & 3358 & 86.7 \\
\hline Primary Education & 713 & 18.4 & N20,000-49,999 & 192 & 5.0 \\
\hline Secondary Education & 1640 & 42.3 & $\mathrm{~N} 50,000$ and above & 41 & 1.1 \\
\hline Post-Secondary Education & 982 & 25.4 & Total & 3591 & 92.7 \\
\hline Total & 3873 & 100 & & & \\
\hline Marital Status & & & Present worth of Business & & \\
\hline Never married & 2427 & 62.7 & Less than $\mathrm{N} 20,000$ & 3181 & 82.1 \\
\hline Married & 1364 & 35.2 & $\mathrm{~N} 20,000-49,999$ & 341 & 8.8 \\
\hline Separated/Divorced & 37 & 1.0 & $\mathrm{~N} 50,000$ and above & 61 & 1.6 \\
\hline Widowed & 45 & 1.2 & Total & 3583 & 92.5 \\
\hline Total & 3873 & 100 & & & \\
\hline Religious Affiliation & & & Products Categories & & \\
\hline Christianity & 2413 & 62.3 & Food, drinks, fruits \& veg. & 2468 & 63.7 \\
\hline Islam & 1442 & 37.2 & Others & 1405 & 36.3 \\
\hline Traditional & 18 & 0.5 & Total & 3873 & 100 \\
\hline Total & 3873 & 100 & & & \\
\hline Ever Injured during Trading & & & Ever Suffered Harassment & & \\
\hline Yes & 954 & 24.6 & Harassed & 1885 & 49.1 \\
\hline No & 2919 & 75.4 & Not Harassed & 1954 & 50.9 \\
\hline Total & 3873 & 100 & Total & 3839 & 100.0 \\
\hline
\end{tabular}

Source: Street Trading Survey 2011.

Table 1 presents the demographic profile of the street traders in the survey locations in Nigeria. The gender distribution shows that 58.4 percent of the street traders interviewed are males while the females are 41.6 percent The age distribution is typical of a developing economy with higher number of respondents in the lower age groups. The result shows that a very large proportion of street traders ( 79 percent) are in the younger age group (15-34 years). The mean age is 28 years, attesting to the preponderance of youths among the street traders in Nigeria. More than three-fifths of the respondents (62.7 percent) have never married, 35.2 percent are married while the remaining 2.2 percent are in the Separated/Widowed/Divorced marital group. While the under-15 are 
excluded by law from the labour force, the result revealed that 1.5 percent of respondents are below 15 years of age.

In terms of formal educational attainment, about 14 percent of the street traders interviewed have never been to school while the remaining 86 percent had undergone regular schooling. Only 25.4 percent have attained above secondary school level, 42.3 percent have had up to secondary school education while 18.4 percent out of all the respondents had only primary education. In addition, the literacy index shows that 70.2 percent of the street traders could read and write in at least in one of the Nigerian languages. Those that could not read or write in any languages constitute only 29.8 percent. However, many of the street traders interviewed understand and speak the Nigeria's abridged English language version ("pidgin" English). In most cases, the interviews were conducted in pidgin, which seemed to be the most popular medium of communication among these traders.

In terms of products being offered for sale, the proportion of street traders that sell food, drinks, vegetables and fruits are 63.7 percent while those that are involved in other product categories are 36.3 percent as indicated in Table 1. In terms of the nature of trading, the result showed that more than half of the respondents (59.3 percent) are peddlers while the remaining 40.7 percent carry on their trading as sedentary sellers in semi-permanent stalls/locations. The latter group consists of sellers that use table tops, makeshift shops, and those that spread their wares on the ground or use display glass boxes by the road side. Employment distribution show that the self-employed are 85 percent while the employees are about 8 percent, while the rest are unpaid family workers, apprentices and others.

\subsection{The Nature and Extent of Occupational Hazards among Street Traders in Nigeria}

\subsubsection{Occupational Hazards in Street Trading: Physical Injury due to Road Traffic Accident}

For this study, two types of occupational hazards are identified: injuries arising from road traffic accidents which may or may not involve loss of wares being sold; and harassment by the public authorities involving arrest and/or lock-up in police cells and confiscation or destruction of wares by the arresting authorities. Table 2 shows the distribution of respondents by the type of harassment ever suffered in the last one year prior to the survey. While 24.6 percent of the street traders have been injured in the course of trading on the street, almost half of those responding to the study's survey have experienced harassment in the course of street trading (Tables 1 and 2). Various forms of harassment suffered by street traders include, but not limited to bullying, beating, seizure of wares, forceful extortions, sexual overtures and/or exploitation and occasional lock-up in police cells pending being bailed by relations and friends.

In terms of age, the youths ( $<25$ years $)$ and the young adults $(25-34$ years $)$ experience the highest injury incidence of 41.3 percent respectively while those in the oldest age-group ( 45 years and above) experience the lowest incidence of injury of 6.4 percent. In general therefore, the incidence of injury is inversely related to the age-group of respondents. With respect to formal educational attainment, those with secondary educational attainment experienced the highest incidence of injury (38.7 percent) followed by those with post-secondary education (28.5 percent). Those with primary education had an injury incidence of 17.6 percent while those with no education suffered the least injury of 15.2 percent. Up to secondary educational level, the level of injury suffered rises with the level of formal educational attainment. Disaggregated by marital status, those that are single (i.e. never married) suffered the highest incidence of injury (67.8 percent), followed by the married ( 30.7 percent) while the lowest incidence of injury is experienced by the last marital group (1.5 percent). In terms of gender, the males are more prone to injury ( 65.5 percent) relative to the females ( 34.5 percent). The incidence of injury varies inversely with the number of years spent in the town of trading as those in the town before 1980 had the lowest incidence of 2.7 percent, those that had been in the town between 1980 and 1999 had 26.1 percent while the latest arrivals (2000-2011) had the highest incidence of 71.2 percent. In terms of the region of origin, street traders from the Northern region experienced the lowest incidence of injury ( 25.3 percent) while those from the Southern Nigeria had 74.2 percent.

The analyses of the incidence of injury between the migrants and the natives shows that the natives experience a lower rate of injury of 44.4 percent, while similar figure for the migrants is 55.8 percent. This is hardly surprising since the natives had stayed longer in the town relative to migrants and therefore have had a good knowledge of how to keep themselves safe from road traffic injuries. Given the fact that street trading by the peddlers involves moving among slow-moving vehicles or at times running after moving vehicles to make sales, one expects the rate of injury to be higher among peddlers compared to the sedentary sellers doing business on a given spot. This conjecture was confirmed by the result of the survey data analysis which reported 57.3 percent injury incidence for peddlers and 42.7 percent for sedentary sellers. Those who have acquired technical skills prior to selling on the street experience a lower rate of incidence of injury (20.6 percent) compared with those 
without other skills (79.4 percent); those who sell on the street and are still looking forward to other types of employment (possibly in the formal sector) experience higher injury incidence (56.8 percent), while the Christians also experience higher injury rate (55.8 percent) than those in the other religious beliefs. With respect to the cities where the surveys were conducted, Port-Harcourt and Aba (representing the East) reported the highest incidence of injury (38.3 percent), followed by Kano in the Northern Nigeria with 32.8 percent, while Lagos (representing the West) had the lowest figure of 28.9 percent.

Table 2. Distribution of respondents by occupational hazards experienced during street trading activities and by some selected characteristics

\begin{tabular}{|c|c|c|c|}
\hline \multirow{2}{*}{ Main Variables } & \multirow{2}{*}{ Derived Variables } & \multicolumn{2}{|c|}{ Type of Hazards (\%) } \\
\hline & & Injured & Harassed \\
\hline \multirow[t]{4}{*}{ Age } & Up to 24 Years & 41.3 & 37.2 \\
\hline & 25-34 Years & 41.3 & 43.3 \\
\hline & 35-44 Years & 11.0 & 14.0 \\
\hline & 45 Years and above & 6.4 & 5.4 \\
\hline \multirow[t]{4}{*}{ Education } & No Schooling & 15.2 & 12.9 \\
\hline & Primary & 17.6 & 16.2 \\
\hline & Secondary & 38.7 & 47.2 \\
\hline & Post-Sec. & 28.5 & 23.7 \\
\hline \multirow[t]{2}{*}{ Gender } & Male & 65.5 & 52.6 \\
\hline & Female & 34.5 & 47.4 \\
\hline \multirow[t]{3}{*}{ Marital Status } & Single & 67.8 & 61.8 \\
\hline & Married & 30.7 & 36.2 \\
\hline & Sep/Div. /Widowed & 1.5 & 2.0 \\
\hline \multirow[t]{2}{*}{ Migration Status } & Migrants & 55.8 & 73.6 \\
\hline & Natives & 44.2 & 26.4 \\
\hline \multirow[t]{3}{*}{ Employment Status } & Self-Employed & 85.0 & 85.5 \\
\hline & Employees & 7.5 & 8.6 \\
\hline & Others & 7.4 & 5.9 \\
\hline \multirow[t]{2}{*}{ Nature of Trading } & Sedentary & 42.7 & 48.8 \\
\hline & Peddling & 57.3 & 51.2 \\
\hline \multirow[t]{3}{*}{ Region of Origin } & Northern Nigeria & 25.3 & 13.2 \\
\hline & Southern Nigeria & 74.2 & 85.6 \\
\hline & Non-Nigerian & 0.5 & 1.3 \\
\hline \multirow[t]{3}{*}{ Survey Zones } & North & 32.8 & 7.2 \\
\hline & East & 38.3 & 42.9 \\
\hline & West & 28.9 & 49.9 \\
\hline \multirow[t]{3}{*}{ Years in Town of Trading } & Before 1980 & 2.7 & 3.3 \\
\hline & 1980-1999 & 26.1 & 27.2 \\
\hline & $2000-2011$ & 71.2 & 69.5 \\
\hline \multirow[t]{2}{*}{ Learnt a Skill? } & Yes & 20.6 & 26.5 \\
\hline & No & 79.4 & 73.5 \\
\hline \multirow[t]{2}{*}{ Looking for other Job? } & Yes & 56.8 & 52.5 \\
\hline & No & 43.2 & 47.5 \\
\hline \multirow[t]{2}{*}{ Religious Affiliation } & Christianity & 55.8 & 76.6 \\
\hline & Others & 44.2 & 23.4 \\
\hline Total & & 24.6 & 49.1 \\
\hline
\end{tabular}

Source: Computed by the authors from Survey Data.

\subsubsection{Occupational Hazards in Street Trading: Harassments from Public Authority Officials}

The last column of Table 2 reports the percentage distribution of those harassed during street trading activities in Nigeria. Unlike the case of injuries which affected 24.6 percent of all sampled respondents, the case of harassment affected 49.1 percent of the street traders surveyed in Nigeria. In terms of age, those in the oldest age group ( 45 years and over) experienced the least incidence of harassment of 5.4 percent while the young adults 
(25-34 years) experienced the highest incidence ( 43.3 percent). This is closely followed by the youths $(<25$ years) with an incidence of 37.2 percent. In terms of formal educational attainment, those with secondary education experience the highest incidence of harassment (47.2 percent) while those in the 'primary' and 'no schooling' categories have 16.2 percent and 12.9 percent respectively. Thus, up to the secondary education level, the extent of harassment increases with formal educational attainment. By gender classification, the males experience higher incidence of harassment ( 52.6 percent) relative to the males ( 47.4 percent). Among the different classifications of marital states, the single experience the highest incidence of harassment (61.8 percent) as compared to the single (36.2 percent) while the Separated/Divorced/Widowed category experienced the lowest level of harassment of 2.0 percent.

Like the case of injury, the number of years spent in the town of trading appears to be indirectly related to the level of harassment received. For instance, those that have spent the longest time (i.e. those that had been in town before 1980) had the lowest level of harassment of 3.3 percent, the 1980-1999 group experience 27.2 percent incidence while the last group who are the most recent arrivals experience 69.5 percent incidence rate of harassment. Evidently, the longer the street traders have been in the respective trading cities, the better is their ability to avoid harassment by the officials of the public authorities. This appears to be in sync with the results obtained for the migration status variable in which the migrants are reported to be having the greater harassment incidence ( 73.6 percent) relative to the natives (26.4 percent). In terms of the city of trading, those in the West (represented by Lagos) experienced the greatest level of harassment (49.9 percent) as compared to those trading in the East (42.9 percent) and North (7.2 percent). This is probably because most of the cities in Southern Nigeria have placed a ban on street trading activities.

Disaggregated by respondents' region of origin, the Southerners reported a higher incidence of harassment (85.6 percent) than those from the Northern part of the country (13.2 percent) and the Non-Nigerians (1.3 percent). In terms of the nature of trading, the peddlers suffer more harassment (51.2 percent) relative to the sedentary sellers (48.8 percent). Disaggregated by the status of respondents in employment, the self-employed suffer the greatest level of harassment (85.5 percent) while for those in the employment of others experience a low level of harassment of 8.5 percent. The respondents who are engaged in street trading as a temporary venture pending the time when a more desirable employment is secured (preferably in the formal sector) experienced a higher level of harassment (52.5 percent), compared to those committed to the sector (47.5 percent). Similarly, a greater proportion of those that have never learnt any other skill prior to selling on the street reported being much more harassed (73.5 percent) than their counterparts with some acquired skills ( 26.5 percent). In terms of religious affiliation, majority of those in the Christian faith (76.6 percent) have experienced harassment relative to the adherents of other religions (23.4 percent).

\subsection{The Probability of Experiencing Occupational Hazards in Street Trading}

The estimation of the basic logit model proposed for this study is presented in Table 3 . The coefficient estimate of each of the explanatory variables shows the influence of each of the variables on the probability of exposure to injury (Table 3, Regression 1) and to the probability of being harassed (Table 3, Regression 2). The result obtained for both types of occupational hazards are shown as Regression 1 and Regression 2 respectively. The model reported in Regression 1 shows that four of the variables are significant at the levels of confidence indicated. The model as a whole explained between 5.4 percent (Cox and Snell R-Squared) and 8.2 percent (Nagelkerke R-Squared) of the variance in the probability of sustaining road traffic injury, and correctly classified 77.8 percent of the cases. The Chi-Square statistic of $71.390(p<0.001)$ indicate that the model is able to distinguish between respondents who experienced road hazards and those that did not within the period specified in the survey instrument. One of the four explanatory variables is significant at the 1 percent critical level while the other three are statistically significant at 5 percent level. The variables are: Religion_Christianity, Search 4 Other jobs, Trade Mode_Sedentary, and average number of days per week spent in street trading.

In the last column of Regression 1, the $\operatorname{Exp}(B)$ or the odds ratio are reported and each of these represents the predicted change in log of odds for a unit increase in the predictor. The sedentary sellers as well as those who are not fully committed to street trading but are searching for other jobs are having $\operatorname{Exp}(\mathrm{B})$ values of 1.439 and 1.391 respectively. Since both values are greater than 1 , it shows that the log of odds of suffering injury in street trading is higher for the respondents to which each of them refers compared to those in the reference category, in a statistically significant sense. Thus, the sedentary sellers and those searching for other jobs have a higher log of odds of experiencing injuries in the street trading occupations. In a similar vein, the respondents who are adherents of the Christian religion have a lower log of odds of suffering injuries in road accidents compared to those in the other religions while the log of odds of sustaining injury reduces as the average number of days spent selling on the 
street per week increases, since the odds ratio is less than unity. For the other explanatory variables, there is no statistically significant difference in the probability of being more or less exposed to injury for street traders.

Regression 2 of Table 3 reports the probability of being harassed in the street trading activities in Nigeria. The explanatory variables included in the model explained between 30.3 percent (Cox and Snell R-Squared) and 40.8 percent (Nagelkerke R-Squared) of the variations in the probability of being harassed. The Chi-Square coefficient is $465.388(\mathrm{p}<0.001)$ showing a very good fit in the model. At a critical level of at most 10 percent, eight of the explanatory variables are found to be statistically significant. Four of these are significant at the 1 percent level, and two each at the 5 percent and 10 percent levels respectively. Gender_Male, Migrant=1, and the two Survey Zone variables belong to the first category of variables having 1 percent statistical level of significance; Age 1, and Religion_Christian belong to the second category while the third category of variables are Age 2 and Days of Trading per week. The most important variable among the explanatory variables is the research location dummy: Research Zone_West, and this is closely followed by the Research Zone_East variable with the odds-ratio values of 46.117 and 10.453 respectively. This shows that street traders in the Western Nigeria (represented by Lagos) and those in the Eastern Nigeria (represented by Aba and Port-Harcourt) are over 46 and 10 times respectively, more likely to be harassed than those in the Northern Nigeria (represented by Kano) which is the reference category.

In terms of gender, the males have a higher probability of being harassed than the females while the migrants experience higher probability of harassment than the natives. The youths in the 'less-than- twenty-five' years' age-grade, experience a higher probability of harassment than those in other age groups. Out of the three continuous variables included in the model, only one of them (Nofdays), the average number of days worked per week was statistically significant at 10 percent critical level. The coefficient estimate of Nofdays has a negative value showing that the higher the number of days worked per week on the average, the less is the respondents' exposure to harassment. This could be due to the fact that such workers have better understanding of the timing of the raids of the 'Task Force' team and as such sneak away from the street before arrest and/or confiscation of articles of trade. Those who are not regular in street trading would have walked into the 'net' of the Task Force team before knowing.

\section{Summary of Findings, Policy Implications and Conclusion}

This study examined two important types of occupational hazards in the street trading activities in Nigeria which are (i) injuries sustained from road traffic accident and (ii) harassment of traders through indiscriminate arrest, seizure and confiscation of merchandise and occasional incarceration of sellers in police cells without trials. The descriptive statistics of street traders show that about 80 percent are in the 15-34 years age range, 68 percent have at least secondary education, 63 percent are single, 61 percent are migrants from other towns and villages in Nigeria in addition to few non-Nigerians interviewed for the study, while 58 percent are of the male gender. Using the binary logit model, the study estimated the log of odds of experiencing occupational hazards in the street trading activities of the urban informal sector. The study found out that in the last one year prior to the survey, 24.6 percent of the traders have suffered one form of injury or the other, while 49.1 percent have experienced one form of harassment or the other. Tables 2 and 3 give a summary of the extent of hazards experienced by the street traders. Harassment is found to be more pronounced among the young, single and male members of the street trading work-force as well as those in Lagos compared to other cities where the study took place.

This study has several implications for policy formulation in Nigeria. Given the high unemployment rate in Nigeria, street trading should be seen as an important aspect of employment creation even if precarious and unstable, in the Nigerian informal economy. This becomes important since there is no form of social safety net and adequate support from the extended family for the unemployed youths (mostly migrants) in Nigerian cities.

Thus, informal sector employment either as a temporary staging post or a permanent life-time career has become one of the mainstays for the economy. Therefore, the paving of streets in Nigeria should be designed as to provide safe trading platforms for street traders. Analogous to walkways, trade-ways should be created along the major streets to enable pedestrians and commuters purchase needed items from traders without the latter facing the risk of injuries from road traffic accidents. Adequate barriers separating the trade-ways from the motorways should be built to prevent traders moving to the street for selling purposes. Also, the government should be committed to providing more employment opportunities for the youths as this will remove many of them from the least desired informal employment of street trading which many of them are involuntarily engaged in, at present. 
Table 3. Binary logit regression result for occupational hazards in street trading in Nigeria

\begin{tabular}{|c|c|c|c|c|c|c|c|c|}
\hline \multirow[b]{2}{*}{ VARIABLES } & \multicolumn{4}{|c|}{ Regression 1: Injured } & \multicolumn{4}{|c|}{ Regression 2: Harassed } \\
\hline & B & Wald & Sig. & $\operatorname{Exp}(B)$ & $B$ & Wald & Sig. & $\operatorname{Exp}(B)$ \\
\hline Age1: $<25$ YEARS & .135 & .270 & .604 & 1.144 & $.596^{* *}$ & 5.408 & .020 & 1.816 \\
\hline Age 2: 25-34 Years & -.057 & .060 & .807 & .945 & $.395+$ & 3.083 & .079 & 1.484 \\
\hline Age $3: 35-44$ Years & -.253 & .859 & .354 & .777 & .420 & 2.650 & .104 & 1.521 \\
\hline Age 4: 45 Yrs and over & (a) & & & & & & & \\
\hline Educ 1: Primary & -.229 & 1.056 & .305 & .795 & -.129 & .299 & .584 & .879 \\
\hline Educ 2: Secondary & -.316 & 2.234 & .135 & .729 & .204 & .869 & .351 & 1.226 \\
\hline Educ 3: Post-Sec. & -.160 & .530 & .467 & .852 & .131 & .316 & .574 & 1.140 \\
\hline Educ 4: No Schooling & (a) & & & & & & & \\
\hline Gender_Male & .132 & .646 & .422 & 1.141 & $.742 *$ & 21.086 & .000 & 2.101 \\
\hline Marstat1_Single & -.085 & .033 & .856 & .919 & .495 & 1.118 & .290 & 1.640 \\
\hline Marstat2_Married & -.560 & 1.597 & .206 & .571 & .532 & 1.443 & .230 & 1.702 \\
\hline Marstat3_Others & (a) & & & & & & & \\
\hline Migrants $=1$ & -.002 & .000 & .994 & .998 & $.979 *$ & 10.315 & .001 & 2.661 \\
\hline Religion_Christianity & $-.619^{*}$ & 9.797 & .002 & .538 & $-.488 * *$ & 4.802 & .028 & .614 \\
\hline Skill Learnt & .199 & 1.498 & .221 & 1.220 & -.006 & .001 & .972 & .994 \\
\hline Searchg4Other job & $.330 * *$ & 4.992 & .027 & 1.391 & -.037 & .060 & .807 & .964 \\
\hline Empt_Self Employment & .085 & .072 & .788 & 1.089 & .480 & 1.972 & .160 & 1.616 \\
\hline Empt_Employee & -.022 & .003 & .954 & .972 & .629 & 2,421 & .120 & 1.876 \\
\hline Empt_Others & (a) & & & & & & & \\
\hline $\begin{array}{l}\text { Trade Mode_Sedentary } \\
\text { Trade Mode Peddling }\end{array}$ & $.364 * *$ & 5.582 & .018 & 1.439 & .178 & 1.407 & .236 & 1.195 \\
\hline Region of Origin_North & .315 & 1.927 & .164 & 1.370 & -.153 & .428 & .513 & .858 \\
\hline Region of origin_others & (a) & & & & & & & \\
\hline Survey Zone_West & -.264 & .904 & .342 & .768 & $3.831^{*}$ & 141.418 & .000 & 46.117 \\
\hline Survey Zone_East & .186 & .335 & .563 & 1.205 & $2.347^{*}$ & 44.596 & .000 & 10.453 \\
\hline Survey Zone_North & (a) & & & & & & & \\
\hline Product Sold_ffbv & -.082 & .307 & .579 & .821 & .234 & 2.443 & .118 & .858 \\
\hline \multicolumn{9}{|l|}{ Product Sold others } \\
\hline Year in Town & -.042 & .498 & .480 & .959 & -.069 & 1.386 & .239 & .933 \\
\hline Sales per week & .012 & .051 & .821 & 1.012 & -.079 & 2.050 & .152 & .924 \\
\hline Days of Trading per wk & $-.187 * *$ & 5.518 & .019 & .829 & $-.235+$ & 6.706 & .010 & .790 \\
\hline Constant & .532 & .362 & .547 & 1.702 & $-2.964 *$ & 9.608 & .002 & .052 \\
\hline$N$ & \multicolumn{4}{|c|}{1291} & \multicolumn{4}{|c|}{1287} \\
\hline Hosmer \& Lemeshow & \multicolumn{4}{|c|}{ Chi-Square: $8.450($ Sig. $=.391)$} & \multicolumn{4}{|c|}{ Chi-Square:6.596 $($ Sig. $=.581)$} \\
\hline Pseudo-R Squared & \multicolumn{4}{|c|}{ Cox\&Snell: .054; Negalkerke:.082 } & \multicolumn{4}{|c|}{ Cox\&Snell:.303; Negalkerke:.408 } \\
\hline Omnibus Test of Coeff. & \multicolumn{4}{|c|}{ Chi-Square: $71.390 ;($ Sig. $=.000)$} & \multicolumn{4}{|c|}{ Chi-Square: 465.388 (Sig.: .000) } \\
\hline Overall Percentage & & 77.8 & & & & 58.4 & & \\
\hline
\end{tabular}

Note. $*$ Significant at 1 percent level, $* *=$ Sig. at 5 percent Level $+=$ Significant at 10 level. Source: Computed by the authors from Survey Data.

Another important implication for policy in this study is the resilience of operators of informal street trade in spite of the high level (49.1 percent) of harassment to the operators. Given the fact that the number of traders do not decline with the number and intensity of street traders' harassment, there is a need for a change of strategy towards urban environmental protection. Rather than the present method of Task Force harassment of street traders, a persuasive approach, emphasising street traders' enlightenment and education on the dangers of street selling hazards is expected, over a long haul, to reduce the street trading menace. This strategy, reinforced by the provision of alternative selling points and increased formal sector employment opportunities is expected to reduce informal sector occupational hazards in general and those of street trading in particular. Finally, government policy should focus more on integrated national development and employment generation in both the rural and urban areas of the country to stem the tide of lopsided urban-biased migration to the few developed cities in Nigeria. For instance, this study showed that the migrants among the street traders are as high as 61 percent; and a policy of integrated development is expected to reduce this rural-urban influx to the barest minimum in the long run.

\section{Acknowledgements}

The authors appreciate the Covenant University's Centre for Research and Development (CUCERD) that provided a generous grant for this research work. 


\section{References}

Becker, G. S. (1975). Human capital. New York: Columbia University Press. http://dx.doi.org/10.7208/chicago/9780226041223.001.0001

Bhowmik, S. (n.d.). Urban responses to street trading. India.

Branigin, W. (1997). Sweatshops once again common in US. The Washington Post, 16.

Callaway, A. (1964). Nigeria's indigenous education: The apprentice system. ODU. Journal of West African Studies, 1(1).

Comaru, F., \& Edmundo, W. (2013). The Health of Workers in Selected Sectors of the Urban Economy: Challenges and Prospects'. Working Paper No. 288; Sectoral Activities Department; ILO, Geneva.

Dorman, P. (2000). The economics of safety, health and well-being at work: An overview. InFocus Program on Safework. International Labour Organisation, Geneva.

International Labour Organisation. (2002). Women and Men in the Informal Economy: A statistical picture. Employment Sector, International Labour Office, Geneva.

Lund, F., Nicholson, J., \& Skinner, C. (2000). Street trading. Durban: University of Natal, School of Development Studies.

McConnell, C. R., Brue, S. L., \& Macpherson, D. A. (2010). Contemporary labour economics (9th ed.). McGraw-Hill.

Mincer, J. (1974). Schooling, experience and earnings. New York: Columbia University Press.

National Bureau of Statistics. (2010). National manpower stock and employment generation survey. Abuja, Nigeria.

Ogunrinola, I. O. (1991). Employment and Earnings in the Urban Informal Sector of Ibadan. An unpublished $\mathrm{PhD}$ Thesis submitted to Obafemi Awolowo University, Ile-Ife Nigeria.

Ogunrinola, I. O. (2011). Social capital and the distribution of earnings of female micro-entrepreneurs in rural Nigeria. African Journal of Economics and Management Studies, 2(1), 581-593. $\mathrm{http}: / / \mathrm{dx}$.doi.org/10.1108/20400701111110795

Rafei, U. M. (2004). Strengthening the foundations of health in South-East Asia. Selected Speeches by Dr. Uton Muchtar Rafei, Regional Director, WHO South-East Asia Region, Volume III, 2001-2004. New Delhi: WHO Regional Office for South-East Asia.

Roever, S. (2006). Street trade in Latin America: Demographic trends, legal issues and vending organisations in six cities. Prepared for the WIEGO Urban Policies Program.

Schultz, T. W. (1961). Investment in human capital. American Economic Review, 51, 1-17.

Smith, A. (1776). An inquiry into the nature and causes of the wealth of nations. London: Methuen \& Co. Ltd.

Tsitsi, D. (2003). Street Vending in Zimbabwe. Harare: Women and Law in Southern Africa (WLSA).

WHO-ILO. (2000). Occupational health for workers in the informal sector. Report of a meeting of WHO-ILO on Occupational Health for Workers in the Informal Sector. Retrieved from http://www.who.int/occupational_health/publications/en/oehafropretoria.pdf?ua=1

\section{Copyrights}

Copyright for this article is retained by the author(s), with first publication rights granted to the journal.

This is an open-access article distributed under the terms and conditions of the Creative Commons Attribution license (http://creativecommons.org/licenses/by/3.0/). 